\title{
Aktualizowanie potencjalności twórczej w kontekście kultury i sztuki a habitus pierwotny - rozważania obrazoburcze?
}

\begin{abstract}
Niewątpliwie w sztuce znamy potężne nieśmiertelne czyny, lecz twórczość artysty polega na emanowaniu własnej potrzeby, własnej tęsknoty, nie zaś - na działaniu pod wpływem cudzego cierpienia lub potrzeby. (...) chodzi o koordynację wzruszeń, zespolonych z dziełem estetycznem (...) Twórczość artystyczna pojęta jako wielki mus uzewnętrzniania pragnień osobistych, posługuje się pewnq skalq środków.
\end{abstract}

L. Konopacki

\begin{abstract}
Abstrakt
W tekście przedstawiono inicjalne badania jakościowe związane z estetyką szkoły, które ilustrują problem uwzględnienia kulturowego habitusu ucznia w edukacji do twórczości, a także konieczność koncentrowania się na indywidualnych potrzebach, zwłaszcza w zakresie poczucia sprawstwa dziecka.
\end{abstract}

Słowa kluczowe: potencjalność twórcza, edukacja estetyczna, habitus.

\section{Updating creative potentiality in the context of culture and art and the original habitus - iconoclastic considerations?}

\begin{abstract}
The text presents initial qualitative research related to the aesthetics of school, which illustrates the problem of taking into account the cultural habitus of the student in education to creativity, as well as the need to focus on individual needs, especially in the scope of a child's sense of empowerment.
\end{abstract}

Keywords: creative potentiality, aesthetic education, habitus.

\footnotetext{
* Uniwersytet Śląski w Katowicach, Wydział Pedagogiki i Psychologii, Instytut Pedagogiki, Zakład Pedagogiki Twórczości i Ekspresji Dziecka.
} 
Twórczość dziecka będąca niewątpliwie efektem jego potencjalnych zdolności, ale i stymulujących oddziaływań środowiska, często spowinowacona zostaje ze sztuką - albo jako jeden z jej przejawów (w sensie wytwórczym), albo efekt, jeśli wykorzystujemy sztukę jako komponent inspiratywny. Dodajmy, że przecież

wszelkie tworzenie, (...) jest takim przynoszeniem (Holen), stanowi czerpanie (przynosić wodę ze źródła). Nowoczesny subiektywizm oczywiście błędnie rozumie to, co twórcze, od razu jako genialne osiągnięcie wspaniałego przez się podmiotu. Ustanawianie prawdy jest ustanawianiem $\mathrm{w}$ znaczeniu nie tylko swobodnego darowywania, lecz zarazem ustanawianiem w sensie takiego kładącego-fundament (grund-legend) zakładania (Heidegger 1992: 56).

Twórczość wymaga inicjacji, pobudzenia aktywności, zaciekawienia i zdziwienia. Musi mieć narzędzia do wyrażania siebie, wymaga więc przygotowania, wiedzy i umiejętności oraz pola środowiskowego będącego zaczynem czy, jak chce Martin Heidegger, fundamentem. Wówczas powiemy, że twórczość dziecka swoiście nawiązuje do tego, co mieści się w jego doświadczeniu kulturowym ${ }^{1}$ - także w przekazach artystycznych, jakie konstytuują, może bardziej wypełniają jego najbliższe otoczenie. Chodzi bowiem o cały zakres habitusu estetycznego, z jakiego wyrasta mały człowiek. Złożą się nań teksty kultury: otoczenie wizualne, muzyka, doświadczenia teatralizacyjne, literackie, z jakimi styka się w domu rodzinnym czy otoczeniu zamieszkania, a które to łącznie decydują o formowaniu się jego smaku i gustu estetycznego. Oczywiście warunkiem inicjalnym jest jakiekolwiek istnienie otoczenia kulturalnego, z jakim obcuje kilkulatek przez pierwsze 3-5 lat swojego życia. Moim założeniem nie jest jednak dołączenie się do chóru utyskujących na nędzę kulturalną polskiego społeczeństwa, na prymitywizację kontaktów ze sztuką, na powszechnie wyzierające z przekazów medialnych kicz i przemoc symboliczną. Nie oznacza to jednak, że tych zjawisk nie zauważam. Ale raczej chciałabym wskazać, iż pierwsze, socjalizacyjne zanurzenie w kulturze, sięgnięcie do istoty obcowania z estetyką winniśmy traktować jak ów habitus pierwotny. Wprawdzie nie zawsze musi się on nam podobać ze względów czysto pedagogicznych, to jednak musi być brany po uwagę, jeśli pragniemy stać się przewodnikiem w kierowaniu dziecka ku sztuce, własnemu tworzeniu, ale przede wszystkim, jeśli chcemy uczynić jego gust/smak estetyczny bardziej wysublimowanym. Jest to o tyle istotne, o ile przyjmiemy, że jedną z kluczowych idei edukacji jest stymulowanie konstytuowania się homo aestheticus. Ów smak, bowiem,

jako estetyczna władza sądzenia - w przeciwieństwie do sądów poznawczych (logicznych) operujących pojęciami - służy do oceniania tego, co jest piękne. Sądy smaku są zdolnością oceniania wyłącznie na odczuciach. Sądy estetyczne jednostek, mimo że są subiektywne, należy traktować jako ubiegające się (pre-

1 Zwanym również referentem kulturowym. 
tendujące) do uznania za powszechne. Każdy z nas, wydając sąd estetyczny, przypisuje innym podmiotom to samo upodobanie (poczucie piękna) zwane przez Kanta zmysłem wspólnym (Han 2014: 208).

Okazuje się więc, że na osobach odpowiedzialnych za proces budzenia się sądów estetycznych, czy szerzej inicjowania świadomych kontaktów z kulturą i sztuką spoczywa ogromna odpowiedzialność. I tym właśnie - ową odpowiedzialnością chcę w niniejszym opracowaniu się zająć.

Aby nie pozostać gołosłowną, przedstawię sygnalnie pilotażowe wyniki badań Zakładu Pedagogiki Twórczości i Ekspresji Dziecka Uniwersytetu Śląskiego², jakie przeprowadzone zostały w roku szkolnym 2016/2017 wśród nauczycieli i uczniów, a poświęcone edukacji estetycznej. W niniejszym artykule skoncentruję się na wybiórczych, acz reprezentatywnych przykładach wypowiedzi respondentów, zaś poruszone wątki będą bezpośrednio wynikały z zauważonych przez informatorów, „szkolnych tubylców”, jakby powiedział Clifford Geertz (2005: 109), cech szkolnej edukacji przez sztukę. Badani uznali je za mające decydujące znaczenie w rozwijaniu kompetencji kreacyjnych, czyli w naszym rozumieniu istotnie wpływających na aktualizację potencjalności twórczej dziecka. Na potrzeby tych rozważań wyłonię jedynie zagadnienia związane z warunkami stymulowania twórczej potencjalności ucznia, które koincydentnie wiążą się z zanurzeniem dziecka w kulturze i sztuce. Rozpocznę od kulturowego habitusu pierwotnego nabywanego socjalizacyjnie w środowisku wzrostu dziecka, stanowić to będzie pierwszy analizowany przeze mnie wątek.

\section{Wątek 1 - socjalizacyjnie generowany kod ekspresyjny a kod odbioru sztuki i tworzenia}

Rozpocznijmy od istoty tworzenia, ale nie analizując powszechnie znanych definicji, lecz sięgając do nieco zapomnianego - chyba niesłusznie - znawcy zagadnienia. Warto bowiem skoncentrować się na - postulowanym przez przywołanego na wstępie Leszka Konopackiego (1921: 5) - uzmysłowieniu sobie pewnych konieczności osobistych, jakie są udziałem kreatora. I choć minęło od powstania słów motta niemal 100 lat, to nie zmienia to trafności cytowanej konstatacji. Tworzenie jest bowiem wypełnione potrzebą ekspresji, wyrażania siebie, zakomunikowania otoczeniu tego, co dla nas ważne. Nie bez znaczenia jest nasycenie tego procesu wyrażania siebie emocjami. W tym miejscu konieczne wydaje się ponowne odwo-

\footnotetext{
2 Badania miały charakter jakościowy, analizie poddano narracje 65 informatorów/pedagogów (głównie ze szkół podstawowych i ponadgimnazjalnych) oraz 201 absolwentów rekrutujących się z odmiennych typów i poziomów szkół, zwłaszcza południowej Polski. Wypowiedzenia gromadzone były na drodze elektronicznej, a ich zestawienie pozwoliło wyłonić zasadnicze wątki poruszane przez respondentów i dokonać ich systematyzacji. Posłużono się podczas analizy i interpretowania ideą horyzontalizacji (Moustakas 2001).
} 
łanie do myśli Martina Heideggera, który stanowczo sytuował wagę przeżycia estetycznego:

niemalże od początków istnienia rozmyślań o sztuce rozmyślanie to nazwane jest estetycznym. Estetyka traktuje dzieło sztuki jak przedmiot, i to jak przedmiot aisthesis, postrzegania zmysłowego w szerokim znaczeniu. Postrzeganie to bywa obecnie nazywane przeżywaniem. Sposób przeżywania sztuki przez człowieka powinien pouczać o jej istocie. Przeżycie stanowi miarodajne źródło nie tylko delektacji sztuką, lecz również tworzenia sztuki. Wszystko jest przeżyciem (Heidegger 1992: 59).

Tworzenie bazuje więc na przeżywaniu, emocje stają się polem konstruowania nowych idei, dzieł, pomysłów. Nie bez znaczenia pozostaje tło emocjonalne przypisywane elementowi inspirującemu dziecięce tworzenie, a zatem owemu przedmiotowi aisthesis. Rzadko odnosimy się do styczności sztuki i tworzenia, poszukując raczej warunków recepcji dzieła sztuki czy komunikatu kulturowego. Mniej zajmuje nas edukacyjnie pojmowane ewokowanie działań twórczych za sprawą kontaktu z dziełem. Nieliczne opracowania poszukujące inspiratywnych walorów sztuki dla własnej aktywności artystycznej zajmują się raczej samym dziełem, analizując choćby wartość estetyczną. I choć panuje powszechny sąd, że należy sięgać do sztuki wysokiej w procesie kształcenia (pojawiają się nawet dość stanowcze wskazania, by chronić uczniów przed popkulturą) - to jednak nie wiemy, jak faktycznie kształtowałaby się efektywność tworzenia inspirowanego dziełem wysoce artystycznym czy popularnym.

Utyskiwanie nad faktem, iż dziecko wzrasta w ubogim lub jedynie popularnym otoczeniu kulturowym jest powszechne. Nie sądzę jednak, by nieobecność sztuki była lepsza niż doświadczanie oferty mniej ambitnej. Co więcej, dochodzące do uszu dziecka dźwięki muzyki w otoczeniu pierwszych kontaktów społecznych (zwłaszcza w rodzinie) czy postrzegane przez nie obrazy miejsc oswojonych (także w kształcie ich zastanej estetyki) zostają powiązane z owymi emocjami, o których pisał Konopacki. To pierwsze zetknięcie się z kulturą i w dodatku powiązane z osobami ważnymi dla dziecka. Tymczasem w szkole uczeń dowiaduje się, że muzyka, której słucha lub tworzy jego rodzina, to mało ambitna i kiczowata produkcja. Kto wie, jakie wówczas pojawiają się w umyśle kilkulatka refleksje. A przecież de gustibus non est disputandum - już Immanuel Kant przekonywał, że „na temat smaku można się spierać (aczkolwiek nie dyskutować)” (Kant 1986: 279). Szkoła zaś stara się niejako wyrwać ucznia z otoczenia kulturowego, w jakim on wzrasta, częstokroć niestety dezawuując to, z czym dziecko kontaktowało się przez pierwsze lata życia. Uznaje się bowiem, że kontakt pierwotny nie obejmuje kultury i sztuki wysokiej, więc należy go wyplenić, nie zważa się jednak wówczas choćby na emocjonalny związek ucznia z takowymi przekazami. Czy zatem nie wprowadzać wychowanka w świat szerszej i ambitniejszej kultury? To nie jest 
także właściwa strategia. W finale tego opracowania spróbuję podjąć tę kwestię, sankcjonując i habitus pierwotny, i poszerzając pole doświadczeń kulturowych.

Równie istotne dla tworzenia okazuje się opanowanie konkretnego języka czy raczej kodu ekspresji, który jest cechą indywidualną, można rzec osobniczą. Preferencja w sposobie wyrażania siebie zależy z jednej strony od typu modalności (na temat modalności zob. Krasoń, Majkut-Czarnota 2007: 323-332), czyli najkorzystniejszego $\mathrm{z}$ punktu widzenia potencjału dziecka kanału nadawania i odbioru informacji. Z drugiej zaś od środowiskowo nabytego kodu komunikacyjnego (rozwiniętego lub ograniczonego). Obie te cechy łącznie formułują specyfikę tworzenia. Powiemy zatem, że sposób, ale i materia, jaka jest nośnikiem wyrażania siebie, w dużym stopniu uzależnione są od potencjału środowiska wzrostu dziecka. Tymczasem edukacyjnie zakładamy, że oferta zajęć twórczych i z zakresu edukacji estetycznej jest zunifikowana, czyli całkowicie nie bierzemy po uwagę indywidualnych potrzeb, preferencji i możliwości dziecka. Wyraźnie wyłania się taki wniosek z narracji nauczycieli, których przykłady zacytuję poniżej:

W naszym środowisku bardzo często dzieci mają kontakt z kulturą dopiero w przedszkolu i szkole. Rodzice zaniedbują swoje obowiązki zrzucając wychowanie wyłącznie na szkołę. Konsekwencje widać wraz z dojrzewaniem dzieci. Brak im wsparcia w rodzicach, brak zainteresowania ze strony dorosłych powoduje, że dzieci nie czerpią dobrych wzorców33.

Nauczyciele często nie mają wpływu na codzienność dziecka, wpływy rodzinne. Nie proponują rodzicom/opiekunom uczestnictwa $\mathrm{w}$ kulturze $\mathrm{w}$ obawie przed posądzeniem o wtrącanie się do cudzego życia, byciem nachalnym.

Rzadko następuje obcowanie z żywą kulturą, jak wyjścia do teatru, opery, czy kina. Myślę, że jest to spowodowane brakiem funduszy, albo chęci ze strony rodziców. W naszej placówce dbamy o to, aby były wyjazdy do teatru, opery, przyjeżdżają do nas zespoły ze Szkoły Muzycznej czy Filharmonii, aby uczniowie byli blisko kultury, jednak można zauważyć, że nie wszyscy rodzice zapisują dzieci na takie wyjazdy. Mimo, że jest taka możliwość, to niektórzy odsuwają swoje dzieci od tej możliwości.

Wszystko zależy od placówki i chęci nauczycieli. Wśród dzieci z środowisk zaniedbanych rzadko podejmowane są działania wpajające kulturę, np. poprzez chociażby zachęcenie ich do czytania tekstów literackich autorstwa pisarzy z danego regionu. Jeśli uczeń zostaje wykluczony przez grupę z powodu cech osobowościowych (np. posługuje się tylko dialektem śląskim) nauczyciel powinien reagować na jego wykluczenie i starać się zintegrować go z grupą poprzez różne działania, a nie być ślepym na sytuację.

\footnotetext{
3 Wszystkie wypowiedzi zacytowano zgodnie z pierwotnym brzmieniem, zatem także z kształtem stylistycznym oraz formą nadaną przez poszczególnych respondentów.
} 
Moim zdaniem niebezpieczna jest segregacja uczniów na podstawie pochodzenia, konsekwencje - uczniowie gorzej usytuowani materialnie nie mają możliwości uczestnictwa w życiu kulturalnym poprzez chociażby wyjście do teatru z klasą bądź rodziną.

Powyższe narracje zauważają zaniedbanie rodzicielskie w zakresie kontaktów z kulturą i sztuką, a co za tym idzie także mniejszy zakres kompetencji dla własnego tworzenia dzieci ze środowisk defaworyzowanych. Choć znalazły się też postulaty inkluzyjne, to jednak istotą wypowiedzi jest wskazanie nierównego dostępu do dóbr kultury. Co symptomatyczne - zaniedbanie rodzicielskie uznawane jest za niemożliwe do skompensowania, co oznaczałoby, że szkoła również nie znalazła dobrej drogi dla wyrównania szans uczniów. Oznaczałoby to, że ubolewanie nad wątłymi kompetencjami kulturowymi wychowanków i ich niewyszukanym smakiem/gustem jest jedynym sposobem procedowania edukacyjnego. Jeśli dziecko kontaktuje się tylko z popkulturową papką - to my umywamy ręce, można odczytać ukryte przesłanie wypowiedzi nauczycielskich.

Co zaniepokoiło mnie najbardziej, to fakt, że tylko jedna respondentka wskazała na istotność poznania języka sztuki przez uczniów, do czego niejako awansem zobowiązuje się nauczyciela szczebla podstawowego:

Myślę, że umiejętność posługiwania się językiem i narzędziami przekazu estetycznego i kulturowego opanowywana w szkole podstawowej. W późniejszym wieku uczniowie nie potrafią wyrazić swojego zdania na temat sztuki, coraz częściej posługują się slangiem młodzieżowym.

Z tej wypowiedzi pośrednio wyłania się kolejne oskarżenie, tym razem skierowane do nauczycieli I szczebla edukacji - nie uczymy czytania sztuki, tak jak nie uczymy czytania i interpretowania świata, a jedynie dostarczamy wiedzy z tzw. kompetencji kluczowych. Teatr w szkole podstawowej? Orkiestra dziecięca? Chór? To jedynie fanaberia albo filmowy wizerunek szkoły amerykańskiej z serii teacher movie lub produkcji Disneya. Plastyka zredukowana do rysowania kredkami na małym formacie kartki, przypadkowi nauczyciele muzyki - taki jest przeciętny obraz edukacji estetycznej w polskiej szkole podstawowej. Ale może to tylko minorowy obraz pedagogów, sądzę więc, że interesujące stanie się sięgnięcie do wypowiedzi uczniów (absolwentów, którzy w roku badania zdawali maturę) - także dotyczących specyfiki środowiskowego warunkowania potencjału do tworzenia i działań artystycznych.

nauczyciele nie patrzyli na uczniów jak na jednostkę tylko jak na cała grupę. Nie liczyły się preferencje danej osoby ani zdolności; nie było istne, w jakich warunkach się wychowało, czy rodzina miała pozytywny czy negatywny wpływ. Zainteresowania uczniów nie były w żaden sposób rozwijane, nie dało się w placówce rozwijać talentów ani zainteresowań. 
Nauczyciele wymagali, aby niektóre cechy kształtujące kulturę były wynoszone z domu lecz nie zawsze było to takie proste. $W$ otoczeniu szkoły średniej są różni uczniowie z różnych środowisk domowych i o różnych sytuacjach emocjonalnych. Myślę, że niesie to za sobą duże konsekwencje ponieważ kultura wyniesiona $\mathrm{z}$ domu jest bardzo ważna to pewnego rodzaju podstawa do sposobu w jaki człowiek się zachowuje lecz nauczyciele powinni w bardziej indywidualny sposób podejść do sprawy mówiąc o kulturze.

Wyraźnie pobrzmiewają w narracjach uczniów podobne konstatacje. Szkoła nie jest przygotowana na odmienność potencjału środowiskowego, nie wyrównuje szans, a jedynie sankcjonuje ów brak. Uczeń zaniedbany kulturowo w domu rodzinnym pozostawiony jest samemu sobie.

Co więcej, zauważone zostało przez nastoletnich respondentów także wadliwe budowanie okazji inspirujących uczenie się, ale i sytuacji rozwijających potencjalność twórczą. Dość złowieszczo pobrzmiewają tu następne wypowiedzi:

W szkole wyglądało jak z lat 90, nawet komputery były z tamtego okresu! Jak można uczyć młodzież, przystosowywać do życia, kiedy w sali komputerowej można się przenieść w czasie? Nawet oprogramowanie Windowsa było przestarzałe! Jakie są konsekwencje? Można stwierdzić, że nie było progresu w naszej nauce. Osobiście brakowało mi nutki nowoczesności, współpracy nauczycieli z mediami (np. Youtube czy platformami edukacyjnymi), nowych metod nauczania. Żałuję, że rzadko szkoła dostosowywała się do słów Konfucjusza: „Powiedz mi, a zapomnę, pokaż mi, a zapamiętam, pozwól mi zrobić, a zrozumiem". Konsekwencją było to, że w większości lekcje były nudne (proszę nie włączać do tego treści), a uczeń przestawał się tym interesować, co z kolei prowadziło do tego, iż moi rówieśnicy przestali się uczyć takich przedmiotów.

Wadliwe metody, można tu przytoczyć przykład zajęć z Dziennikarstwa. Nie dano nam szansy poznać pracy dziennikarza. Nigdy nie dowiedzieliśmy się jak wygląda praca w wydawnictwie, czy telewizji, nie byliśmy nawet obserwatorami. Zajęcia były przez to mało efektywne, gdyż słuchaliśmy tylko suchych faktów.

rzadko wychodziliśmy na wyjścia kulturalne nie mieliśmy kontaktu na przykład z profesjonalnym teatrem, prawdziwą, dostępną dla wszystkich sztuką. Myślę że jest to ważne aby być obytym w dziedzinach kultury i aby wiedzieć jak zachowywać się w różnych instytucjach kulturalnych. Wyjścia tego typu pozwalają także na zaszczepienie w sobie pasji do kultury, sztuki. Myślę, że u niektórych osób mogło to spowodować późniejszy brak zainteresowania wychodzeniem do miejsc kulturalnych, ponieważ w trakcie edukacji tego nie robiły.

A zatem uczeń ze środowiska niewydolnego kulturowo otrzymuje w szkole podobnie ubogą ofertę edukacji estetycznej i pozostanie mu jedynie poddanie się dobiegającej zewsząd nachalnie kultury masowej. Dodajmy, nie jest przygotowany na refleksyjny odbiór, na dokonywanie wyboru, czyli też na budowanie własnej twórczości w kontekście tych komunikatów kulturowych. 
Gdzie więc znajdzie się miejsce dla rozwijania myślenia estetycznego, o którym pisał Wolfgang Welsch (przytaczam za Willems-Pisarek 2003: 240)? Zupełnie zapomniano o tym, by młody człowiek mógł swobodnie poruszać się w rozmaitych kierunkach artystycznych, nie ulega jednak wątpliwości, że należy je wcześniej poznać, a może bardziej doświadczyć ich. Jeśli sztuka i jej odmienne pojmowanie ma inspirować nasze tworzenie, należy opanować jej język, analizę i podjąć własną jej interpretację. Musimy być takoż otwarci na odmienność, potrzebna jest zatem strategia intersubiektywnej negocjacji znaczeń. Rozmaite style w sztuce ukazują różniące się optyki analiz i odczytań. Stwarza to szansę na zwielokrotnienie doświadczeń i kształtowanie się skłonności do interpretatywnych debat, które poszerzają nasze doświadczenie. Wiele o tym mówi choćby Józef Tischner w dialogu edukacyjnym (1982).

Niewątpliwie ta nasza zdolność wzbogaca nas wewnętrznie i poszerza naszą wrażliwość. W. Welsch zakłada tu analogię, a zarazem postuluje, abyśmy to wyrobione na gruncie sztuki uwrażliwienie na inność i różnorodność przenosili także na codzienny odbiór otaczającej nas rzeczywistości na wszystkich płaszczyznach (Willems-Pisarek 2003: 240).

Sądzę, że owa odmienność i prawo do niej będzie kluczowym komponentem modelu edukacji estetycznej.

Tymczasem ocena wystawiona przez absolwentów jest niezwykle ostra, atmosfera nie służy rozbudzaniu talentu, aktywności - w tym również aktywności twórczej. Jeszcze widoczniejsze stanie się to podczas analizy kolejnego wątku - dotyczącego zaspokajania potrzeby wyrażania siebie.

\section{Wątek 2 - potrzeby ucznia i chęć ekspresji siebie}

Oddajmy tym razem najpierw głos uczniom. Oto narracje stanowiące swoiste podsumowanie tego, co najbardziej zaniedbywano w edukacji instytucjonalnej, a z czym młodzi dorośli nie chcą się zgodzić.

W mojej szkole kładziono duży nacisk na jak najlepsze oceny czy frekwencję. Zaniedbywano w ten sposób uczniów jako ludzi, którzy poza samą nauką do sprawdzianów mają inne zainteresowania, pasje, które chcieliby rozwijać. W konsekwencji trzeba było poświęcić czas na odrabianie zadań i uczenie się, przez co nie było możliwości samorealizacji, wypracowania swojego zdania, zdobywania różnych doświadczeń życiowych i dzielenia się nimi z innymi. Dodatkowo nie było możliwe wyrażanie siebie poprzez słowa lub mało kto miał chęci do tego, gdyż ważniejsze było to czy nauczyliśmy się danych zagadnień i potrafimy „przelać” tą wiedzę na papier. 
Szacunek wobec tego kim jestem, czego skutkiem był brak realnego poczucia wolności i wyrażania swojego zdania. Tożsamość indywidualna uczniów, którzy często nie mogli przedstawiać swoich poglądów i przedstawiali podglądy szkoły. Uczniom narzucane były poglądy dyrektora na każdy temat kulturowy. Cechy indywidualne każdego ucznia, dyrektor zwracał szczególną uwagę na ubiór każdego ucznia. Innowacyjność nie była mile widziana.

w szkole średniej zwłaszcza przed maturą nie mieliśmy możliwości własnej interpretacji podczas lekcji ponieważ musieliśmy podążać za kluczem odpowiedzi, który miał dać nam pewność zdania matury. Nie byłam tym zachwycona, ponieważ uważam, że każdy człowiek ma prawo do własnej interpretacji. Konsekwencją braku tego komponentu jest zawężenie wyobraźni ucznia i blokowanie jego własnego zdania na dany temat.

W pierwszej klasie technikum mieliśmy przedmiot WOK (wiedza o kulturze) lecz zajęcia prowadzone były w sposób, który zniechęcał ucznia, dodatkowo nie można było w żaden sposób 'podyskutować' na żaden temat, bo trzeba się było dopasować do zdania, które miał nauczyciel, czego konsekwencją moim zdaniem była niechęć ucznia do jakichkolwiek zajęć związanych z kulturą (...) w szkole średniej na języku polskim prawie w ogóle nie interpretowaliśmy tekstów kultury wspólnie, co było sporym problemem, gdyż uczniowie czasem potrzebowali pomocy lub jakiekolwiek nakierowania, aby zrozumieć, $\mathrm{w}$ konsekwencji nikt nie był przygotowany do matury z j. polskiego oraz bardzo dużo osób zrezygnowało z podejścia do niej, ponieważ wiedzieli, że nie poradzą sobie z materiałem i zinterpretowaniem dzieła kultury.

Jaki obraz wyłania się z tych dość przygnębiających wypowiedzi (dodajmy, że inne wpisy informatorów miały podobny wydźwięk, nie odnaleziono żadnej opinii potwierdzającej koncentrację na potrzebach kulturowych ucznia)? Szkoła tworzy coś w rodzaju transmisji jedynie słusznych treści i choć w wielu wpisach na stronach internetowych placówek edukacyjnych znajdziemy deklarację, że ta czy owa szkoła jest dla osób wyjątkowych, w której słucha się głosu ucznia, to - jak się okazuje - nadal są to puste frazesy bez pokrycia.

Spróbujmy zestawić głos młodzieży z opiniami nauczycieli, jakie napłynęły w czasie gromadzenia materiału empirycznego.

W szkole często potrzeby uczniów są niezauważane, a wszystko toczy się według ustalonych wcześniej celów i osiągnięć, które powinny zostać opanowane w ciągu roku. Nie wykorzystuje się w pełni możliwości dzieci, nie dostarcza się im sytuacji, w których mogą wyrażać „siebie”- swoją ekspresję i doświadczenia. Konsekwencją pomijania w wym. komponentów jest brak budowania poczucia ważności swojej osoby w świecie.

Sądzę, iż przez wiele lat zapominano o cechach indywidualnych uczniów, pomijano twórczość, próbując wbić w sztywne ramy „od... do”. Egzaminy, do których nauka była konieczna wedle klucza odpowiedzi. Niewiele szkół tolerowało odmienność czy własne spojrzenie na dany temat. 
Uważam, że pomijane są cechy osobowościowe ucznia i jego potrzeby. Konsekwencją tego jest niechęć uczniów do nauki literatury, sztuk pięknych. Dzisiejsza edukacja ma za zadanie nauczać uczniów systemu klucza, w który należy się wpasować, nie zwracając uwagi na indywidualne potrzeby.

Konsekwencje pominięcia potrzeb mogą być wręcz dramatyczne w skutkach, możemy spowodować, że nieśmiałe dziecko zamknie się w sobie jeszcze bardziej itd. W pracy z dziećmi znajomość ich, ich potrzeb, zainteresowań, deficytów jest kluczowa. Często nauczyciel postępuje i wymaga od uczniów odpowiedzi „zgodnych z kluczem” - jak np. nowa matura, brak wówczas miejsca na swobodną interpretację. Przyczyną tego może być przykładowo chęć wykazania się dobrymi ocenami swoich wychowanków podczas egzaminów zewnętrznych, szybkie tempo realizacji podstawy programowej. To bardzo przykry wniosek, ale moim zdaniem taki sposób stawianych wymagań oraz nauczania zabija kreatywność uczniów, uczy ich podstępowania na zasadzie „nauczyć się - zdać - zapomnieć", nie skłania do refleksji oraz samodzielnego myślenia - co przecież jest bardzo ważnym aspektem edukacji.

nie ma takiego swobodnego wyrażania swoich myśli, przeżyć związanych z sztuką, literaturą. Uczniowie boją się powiedzieć co myślą np. o danym utworze muzycznym, bo może to nie odpowiadać i pasować do jakiegoś tam z góry założonego modelu. W konsekwencji dzieci zamykają się w sobie, chociaż dobrze wiedzą co dla nich dana rzecz może oznaczać, będą to dzieci bez wyobraźni, marzeń, takie które nie będą czerpały radości z obcowania z kulturą. A siła wyobraźni i marzeń ma ogromną moc. Na moim przykładzie, kiedy byłam uczennicą, można powiedzieć że nauczycielka w szkole podstawowej nie wiem czy świadomie czy nie, ale 'zakopała' gdzieś moją pasję do malowania, uznając 'zobacz a Karolinka zrobiła to tak, ładnie a właśnie tak wygląda powiedzmy motyl’. Musimy być świadomi siły znaczeń słów, i musimy pielęgnować w dziecku chęci, jakiś jego punkt widzenia na jakąś pracę plastyczną, czy utwór muzyczny.

(...) gonitwa za wypełnianiem papierologii zabiera czas na poznanie (...) uczniów. Prowadzić to może do wycofania się oraz zahamowania rozwoju ich skrytych talentów literackich, aktorskich, teatralnych.

Może być również tak, iż nauczyciel nie ma wystarczającej wiedzy, by realizować te komponenty, nie zna takiego sposobu pracy z uczniem, lub sztywno trzyma się planu i programu, nie dając wychowankom możliwości twórczego działania. Bądź całą swoją uwagę poświęca na realizowanie innych celów wychowawczych, (...). Konsekwencją (...) może być m.in.: brak wiedzy o swoim wychowanku - jego zainteresowaniach, pasjach, brak szansy na wydobycie potencjału ucznia, brak umiejętności u uczniów wyrażania i uzasadniania własnego zdania, nieumiejętność wyrażania emocji, co przedkłada się na komunikację z drugim człowiekiem.

Czytając wypowiedzi nauczycieli, trudno nie odnieść wrażenia, że stanowią one swoistą samokrytykę. Obraz edukacji estetycznej głęboko osadzony jest w edukacji w ogóle, gdzie sprawdzian kompetencji staje się kluczowym elementem kształtują- 
cym system pracy. Nauczyciele - jak widać - mają świadomość, że działanie takie jest niewłaściwe, ale sami uwikłani zostają w ten opresyjno-egzaminacyjny kierat. Można odnieść wrażenie, że sfrustrowani nauczyciele prowadzą lekcje, które stają się polem powstawania frustracji ucznia.

A szkoły opuszczają młodzi dorośli, którzy nie mieli szansy na przekonanie się, że ich opinia, zdanie mają sens. Co więcej, wkraczają w kolejny akademicki etap kształcenia z przekonaniem o nieistnieniu poczucia sprawstwa czy sensu. I okazuje się, że edukacja akademicka podporządkowana matrycom, formatkom, benchmarkom i enigmatycznie zarysowanym efektom kształcenia oraz kluczowym narzędziom weryfikacji tychże efektów - niejako po drodze - gubi istotę edukacyjnego dialogu. Jeśli jeszcze dodamy, że pedagogiczne środowisko akademickie, częściowo odpowiadające za przygotowanie przyszłych nauczycieli, z niepokojem zerkające na mającą się niebawem ziścić przemianę ustawową, konstytuują badacze przekonani, iż posiedli jedynie słuszną rację, to wizja zaistnienia poczucia sprawstwa jeszcze bardziej się oddala. Ortodoksyjność chociażby widoczna w zakresie metodologii nie zakłada żadnej możliwości polemiki. A może i zakłada, ale z góry skazuje na odrzucenie idei odmiennych. I tak, jednostronnie, kształcimy studentów. I nie usprawiedliwia nas - jak sądzę - fakt, iż kierunki pedagogiczne nie są pierwszym wyborem większości kandydatów, a na rekrutację zgłaszają się osoby bez jakichkolwiek zainteresowań (nie mówiąc już o kulturowym rozeznaniu). W pogoni za weryfikacją efektów i odhaczaniem realizowanych treści tracimy możliwość dialogowego bycia z młodymi ludźmi. Powszechne jest ubolewanie na poziom oczytania czy szczególnych kompetencji młodzieży akademickiej. Czasem udaje się tworzyć faktyczną aurę wolności dyskusji podczas seminariów dyplomowych, zwłaszcza na poziomie studiów III stopnia, ale wówczas słyszymy głosy młodych - zrobię tradycyjne badania, bo niebezpiecznie jest wychylać się. I tak dokładamy kolejną cegiełkę edukacyjną, która zamyka szansę na tworzenie i samorealizację. Ćwiczymy uległość - nie twórczość, a studenci także nie mają szansy na wygenerowanie żadnej własnej myśli, głównie reduplikując źródła, bo to jest sprawdzane.

Czy więc jest jakaś szansa dla dziecka? Myślę, że jest, ale należy jej szukać właśnie w kształceniu akademickim, czyli w przygotowaniu przyszłych nauczycieli. Przy czym najistotniejsza komponenta związana jest z owym habitusem pierwotnym i stwarzaniem możliwości obcowania z kulturą i sztuką.

\section{Dylemat wolności i poprawność wyboru - uwagi końcowe}

Odwołując się do myśli Luca Ferry'ego, dotykamy kluczowego elementu budowania edukacji estetycznej, zawierającego w sobie zasadniczą - i wydaje się - nie do pogodzenia sprzeczność: „jak zachować ideę możliwej uniwersalności smaku, bez zasady tego zdrowego rozsądku negującej podmiotowość otrzymaną (...) jako humanizmu ludzkiego" (Han 2014: 206). Słowem, jak umożliwić uczniom z jednej 
strony wyrażanie się kodem kulturowym, jaki wynieśli z domu rodzinnego, opartym na ofercie estetycznej danej grupy społecznej, a jednocześnie rozbudzać nową potrzebę edukacyjną, zakładającą rozszerzanie pola komunikatów kulturowych i opanowanie języka sztuki. Inaczej zadamy pytanie, jak zachować indywidualność bez formuły, że każdy ma prawo do własnego gustu, co jednak niszczy uniwersalność?

Sądzę, że jedyną odpowiedzią jest stworzenie aury negocjacji. A zatem nie narzucamy oferty estetycznej arbitralnie, negując to, z czym przychodzi uczeń do szkoły. Ale właśnie bazując na jego habitusie pierwotnym, bierzemy pod uwagę to, co buduje jego wrażliwość estetyczną. Słuchamy ucznia, w żadnym razie nie dezawuując jego doświadczeń kulturowych. Musimy poznać jego smak/gust i dopiero na tej podstawie oferować mu zakres alternatywny. Czasem wszak negacja jakiegoś wycinka rzeczywistości kulturalnej wynika zwyczajnie z niewiedzy.

Oto przykład z innych badań własnych. Małe dzieci doskonale radzą sobie z interpretacją obrazów surrealistów, świetnie ich ogląd sprawdza się chociażby podczas inspiracji dla ćwiczeń teatralizacyjnych. Kiedy jednak pierwszy raz pokazałam obrazy będące punktem wyjścia do tworzenia scenek wizualizacyjnych nauczycielom, stwierdzili, że są one zbyt trudne i dzieci z pewnością nic nie będą umiały o nich powiedzieć, a cóż dopiero budować twórcze działania. Jaka jednak była faktyczna lekcyjna realizacja? Uczniowie klasy I całkowicie zanurzyli się w świat fantazji, obrazy ukazujące wizje niedookreślone, otwarte na nadawanie znaczeń nie sprawiły im kłopotu. Wręcz przeciwnie, spowodowały oryginalne opowieści, które zostały zainscenizowane $\mathrm{w}$ postaci scenek/etiud ruchowych. I bezcenna reakcja wychowawcy - „nie wiedziałam, że moje dzieci mogą mieć takie pomysły”.

Inna scenka z praktyki pedagogicznej. Nauczycielka w jednym z katowickich przedszkoli, mając hospitację (zapowiedzianą), podczas zajęć chciała wykorzystać tekst literacki jako inspirację dla podjęcia działań plastycznych. Posłużyła się telefonem komórkowym, z którego w wielkim skupieniu, kilkakrotnie niechcący przewijając treść i gubiąc się $\mathrm{w}$ narracji, odczytała materiał literacki. Trudne do pojęcia? Odczytanie bez interpretacji głosowej, bez ilustracji, a w finale polecenie narysowania ulubionego bohatera (!). Czy taki obrazek nie jest nam znany także z sal uniwersyteckich zajęć? A prace uczestników? Rysunki wykonane, ale dzieci nie chciały o nich opowiadać, prosząc, by mogły już bawić się zabawkami. Liczy się zatem nie tylko obecność sztuki, ale też umiejętności w organizowaniu zajęć, w których sztuka będzie inspirowała przygodę intelektualną. Nieudolne odczytanie tekstu, bez właściwego przygotowania jest jednym $\mathrm{z}$ zasadniczych uchybień w prowadzeniu zajęć opartych na kulturze. Tu rola nauczyciela będącego pośrednikiem pomiędzy komunikatem kulturowym a małym odbiorcą jest wiodąca.

Jeśli nie damy szansy na dobrze zorganizowany kontakt ze sztuką współczesną i nie dopuścimy, by dziecko na początku odczytywało ją przez pryzmat własnego kodu kulturowego - nie dowiemy się, że ma ono „swoje pomysły”. Co jednak jest potrzebne, by mogły być realizowane postulaty twórczej edukacji estetycznej? 
Myślę, że jednym z zasadniczych komponentów jest czas, który damy nauczycielowi, zwalniając go z obowiązku realizowania sztywnych ram, schematów i egzekwowania jedynie słusznych interpretacji. Niech stworzy szansę, by odkrywać świat sztuki i przekodowywać go na systemy semiotyczne przyrodzone dziecku ruch, obraz, zabawę inscenizacyjną. Niech ma czas na wizytę w teatrze, galerii, sali koncertowej. Takie założenie wymaga także tego, by studenci pedagogiki również mieli czas na prawdziwy, refleksyjny kontakt z kulturą i sztuką (jakoś tych efektów kształcenia próżno szukać we wzorcowych zestawach dla pedagogów). Pamiętając słowa wybitnego znawcy edukacji estetycznej - Bogdana Suchodolskiego:

potrzeby kulturalne rodzą się jako mętne tęsknoty i pragnienia. Jeśli nie znajdą zaspokojenia, jeśli raz i drugi „źle trafią” - słabną i przygasają. Jeśli jednak człowiek znajdzie to, czego rzeczywiście pragnął, rozbudzają się jego potrzeby kulturalne coraz bardziej i stają się coraz śmielsze (...). Człowiek rozbudzony sięgać będzie raz po raz po dalsze rady i wiązać się będzie coraz głębiej z dorobkiem kultury (Suchodolski 2006: 265).

Dodajmy, będzie też rozwijał potrzebę aktualizacji własnego potencjału twórczego.

\section{Bibliografia}

Geertz C. (2005) Sztuka jako system kulturowy w: C. Geertz, Wiedza lokalna. Dalsze eseje z zakresu antropologii interpretatywnej, przekł. D. Wolska, Kraków, Wydawnictwo Uniwersytetu Jagiellońskiego.

Han T. (2014) Zdroworozsq̨dkowe dygresje w problematyzacji Homo aestheticus autorstwa Ellen Dissanayake oraz Luca Ferry'ego w: Aesthesis i Ratio. Człowiek w przestrzeni kultury i estetyki, J. Krasicki, T. Akindynowa, Z. Pietrzak (red.), Wrocław, Oficyna Wydawnicza Arboretum, s. 206-211.

Heidegger M. (1992) O źródle dzieła sztuki, „Sztuka i Filozofia”, nr 5, s. 9-67.

Kant I. (1986) Krytyka władzy sądzenia, tłum. J. Gałecki, Warszawa.

Konopacki L. (1921) Kultura uczuć w stosunku do dziejów życia, Warszawa, skład główny Księgarnia Perzyński, Niklewicz i S-ka.

Krasoń K., Majkut-Czarnota B. (2007) Szansa na porozumienie $w$ diadzie nauczyciel - uczeń a poznanie preferencji modalnych dziecka w: Edukacja w społeczeństwie „ryzyka", t. 3, Bezpieczeństwo jako wartość, M. Gwoździcka-Piotrowska, J. Wołejszo, A. Zduniak (red.), Poznań, Wydawnictwo Wyższej Szkoły Bezpieczeństwa, s. 323-332.

Moustakas C. (2001) Fenomenologiczne metody badań, przekł. i red. S. Zabielski, Białystok, Trans Humana. 
Suchodolski B. (2006) Problemy i metody uspołecznienia kultury w: Edukacja i kultura. Idea i realia interakcji, I. Wojnar (red.), Warszawa, Polska Akademia Nauk, kancelaria Komitet Prognoz „Polska 2000 Plus”, Aneks.

Tischner J. (1982) Myślenie według wartości, Kraków, Wydawnictwo „Znak”.

Willems-Pisarek M. (2003) Teza W. Welscha o modelowej roli sztuki dla współczesnej rzeczywistości i myśli filozoficznej na tle inspiracji późna filozofiq L. Wittgensteina, „Sztuka i Filozofia”, nr 22/23, s. 230-252. 